\title{
急性期脳梗塞診断に対する ヘリカルスキャンの適用に関する検討
}

\author{
浜口直子・小寺秀一
}

札幌麻生脳神経外科病院放射線科

\section{緒 言}

頭部単純 CT は急性期脳梗塞の診断や治療方針の 決定に用いられており, ASIST JAPANの撮影ガイド ラインが診断に有用であることは周知である ${ }^{1,2)}$. 一 方， CT 装置の進歩により良質なボリュームデータの 取得が可能になった現在, ヘリカルスキャンによる データ収集は multi planner reformat(MPR)の作成, 撮影時間の短縮等利便性が高く，さまざまな部位の 診断に広く用いられている．特に急性期脳梗塞の症 例では，撮影時間が短いへリカルスキャンを用いること は大きな魅力であり，また読影が難しい早期虚血変 化の診断において左右対称な画像を MPRにより提 供することは，臨床上有用であることが推測される.

しかし, 頭部単純 CT に関しては未だノンヘリカル

\begin{abstract}
スキャンが主流であり，ガイドラインにおいてもノン ヘリカルスキャンの使用が勧められている1).

そこで今回，ノイズレベルが同等となるような撮影 条件にてノンヘリカルスキャンとヘリカルスキャンの 比較を行い, 大脳基底核レベルの早期虚血変化の検 出におけるへリカルスキャン MPRの臨床応用に向け ての検討を行った。
\end{abstract}

\section{1. 方 法}

\section{1-1 使用機器}

LightSpeed VCT: 64DAS CT 装置 (GE healthcare 製) SIGNA EXCITE HD TwinSpeed version12: $1.5 \mathrm{~T}$ MR 装置 (GE healthcare 製)

Advantage Workstation Volume Share2: 画像処理

\section{Potential of Helical Scan Technique in Acute Cerebral Infarction Assessment \\ Naoko Hamaguchi, and Shuuichi Kodera \\ Department of Radiology, Sapporo Azabu Neurosurgical Hospital \\ Received July 30, 2009; Revision accepted April 1, 2010; Code No. 251}

\section{Summary}

The high convenience of data collection by helical scanning, such as making multi planner reformat (MPR) and shortening scan time, means that the technique is widely used to diagnose various body parts. However, non-helical scanning is still a main current for plane brain computed tomography. The possibility of diagnosing acute cerebral infarction by helical scanning MPR was examined. It was found that image degradation in helical scanning had little influence on the physical evaluation of the characteristics of modulation transfer function and the noise power spectrum, etc. In the evaluation of the ischemic change occurring at the early stage made by examination of clinical images, the result was almost equal to that obtained by non-helical scanning, as the reported sensitivity was $52 \%$ and the specificity was $95 \%$. This suggested that brain helical scanning MPR might be applied clinically. However, a disadvantage was confirmed as helical scanning had a higher exposure dose than non-helical scanning at the start and end of scanning. The results of this study indicated that helical scanning demonstrates sufficient convenience for the assessment of acute cerebral infarction at the basal nucleus level.

Key words: early CT changes, brain CT, helical scan, acute ischemic stroke, early CT sign 
ワークステーション (GE healthcare 製)

第二次勧告準拠 低コントラスト分解能評価用 ファントム(旭メディカル社製)

装置付属 $25 \mathrm{~cm} \phi$ 水ファントム (GE healthcare 製)

\section{1-2 ヘリカルスキャン撮影条件の設定}

今回の検討では，ガイドラインに定めるとおり急性 期脳梗塞に対しへリカルスキャンを用いることが低コ ントラスト分解能の劣化につながるのかという問題を 明確にすることが第一の目的である。そこで，へリカ ルスキャンを行うことによる画質の劣化を確認するた めに，急性期脳梗塞臨床例に対しへリカルスキャン を行うことを想定し, 事前にヘリカルスキャンの撮影 条件を設定した，急性期脳梗塞における単純 CT は, ガイドラインにおける早期虚血病変の定義より, 皮髄 境界や脳溝が明瞭に描出され, さらにある程度主要 血管の同定ができるような撮影条件が必要であると 考えられる ${ }^{1)}$. 前述の条件を満たすため, 当院では脳 の構造体の CT 值を参考にし, 均一な物質の関心領 域における CT 值の標準偏差 (standard deviation: SD) を基準に決定している3). 白質, 灰白質, 浮腫の CT 值差は平均で 5〜10 HUである。この CT 值差を判別 するために必要な画像 SD は統計学的に考えると 2 3 程度である ${ }^{4)}$. これより画像 SD が 2 3の範囲内に なるように基底核レベルの撮影を行っている.へリカ ルスキャン MPR にて同等な画像 SDになるような撮

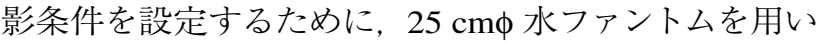
ノンヘリカルスキャン, ヘリカルスキャン MPRの画像 $\mathrm{SD}$ を測定した。ノンヘリカルスキャンの撮影条件は 管電圧 $120 \mathrm{kV}$, 管電流 $580 \mathrm{~mA}$, 回転時間 $1.0 \mathrm{~s}$, ス ライス厚 $5.0 \mathrm{~mm}(0.625 \mathrm{~mm} \times 32)$ で, ヘリカルスキャンの 撮影条件は管電圧 $120 \mathrm{kV}$, 回転時間 0.5 秒, ピッチ $0.531 ： 1$ で設定スライス厚 $0.625 \mathrm{~mm}$, ビーム幅 $20 \mathrm{~mm}$ (0.625 mm×32), MPR にてスライス厚 $5.0 \mathrm{~mm}$ とし, 再構成関数はどちらも Standardとした。臨床にへリ カルスキャンを用いることを想定して CT auto exposure control(CT-AEC)を使用することとし，CT-AECにお ける目標 SD 值 (noise index: NI) 5.0〜 10.5 まで変化 させ撮影を行った。画像 SD の測定は 5 点の関心領 域 (region of interest: ROI) で 5 回測定した平均值を結 果とした.

また，臨床では被曝線量を考慮する必要があるが, ヘリカルスキャンにてノンヘリカルスキャンと同一範 囲を撮影する場合, スキャンの開始と終了の画像に 寄与しない部分の被曝が多くなるのは必然である. これにより, 同一画像 SD を得るための撮影を行った 場合, ヘリカルスキャンの方が被曝量は増大することに なる. $25 \mathrm{~cm} \phi$ 水ファントムを用いて, 同一範囲 $(35 \mathrm{~mm})$
をノンヘリカルスキャンとヘリカルスキャンで撮影した ときの装置表示の CT dose index(CTDIvol) と dose length product(DLP)を記録した. このときのノンヘリ カルスキャンの撮影条件は管電圧 $120 \mathrm{kV}$, 管電流 $580 \mathrm{~mA}$, 回転時間 $1.0 \mathrm{~s}$, スライス厚 $5.0 \mathrm{~mm}(0.625$ $\mathrm{mm} \times 32)$ で，ヘリカルスキャンの撮影条件は管電圧 $120 \mathrm{kV}$, 回転時間 $0.5 \mathrm{~s}$, ピッチ $0.531: 1$, スライス 厚 $0.625 \mathrm{~mm}(0.625 \mathrm{~mm} \times 32)$ で CT-AECを使用し, NI は 5.0〜8.0 とした。なお，CT-AECを使用した場合は 管電流が変調するが，当装置にて CT-AECを使用し た場合，表示の CTDIvol は平均值を示す。

さらに，へリカルスキャンを使用したときに，被曝 を低減させるために非線形量子フィルタを付加し,

MPR のスライス厚を厚くすることにより画像 SD の改 善を罒ることを考えた，当院の CT 装置に搭載の非線 形量子フィルタ(Neuro3DFilter)は, 構造物の有無を 3 次元的に認識し, その方向性を加味したシャープ化, スムージング化を行うフィルタであり，N1，N2，N3 の 3 つの設定があるが，今回はノイズ分布に最も影響 を及ぼさないと予想される N1 を使用することとした. MPR のスライス厚を決定するために, $25 \mathrm{cm \phi}$ 水ファ ントムを用いて SD 測定を行った。撮影条件はノンへ リカルスキャンでは管電圧 $120 \mathrm{kV}$, 管電流 $580 \mathrm{~mA}$, 回転時間 $1.0 \mathrm{~s}$, スライス厚 $5.0 \mathrm{~mm}(0.625 \mathrm{~mm} \times 32)$, ヘリカルスキャンは管電圧 $120 \mathrm{kV}$, 管電流 CT-AEC (NI: 6.5, 7.0), 回転時間 $0.5 \mathrm{~s}$, ピッチ $0.531: 1$, スラ イス厚 $0.625 \mathrm{~mm}(0.625 \mathrm{~mm} \times 32)$ で行い, ヘリカルス キャンでは Neuro3DFilter N1 を付加した.

\section{1-3 物理特性評価}

1-3-1 スライス面内 modulation transfer function (MTF) の比較

ノンヘリカルスキャンとヘリカルスキャンのスライ ス面内空間分解能を確認するために, ワイヤーファン トムを撮影し MTF 測定を行った ${ }^{5)}$ 。測定は撮影視野 (field of view: FOV)の中心，また中心より $5 \mathrm{~cm}$ 外側の 2 点にて行った。撮影条件は，ノイズの影響を少なく するような条件設定を行い, ノンヘリカルスキャンと ヘリカルスキャンの画像 SD が約 1.5 となるように設 定した.ノンヘリカルスキャンは管電圧 $120 \mathrm{kV}$, 管 電流 $200 \mathrm{~mA}$, 回転時間 $1.0 \mathrm{~s}$, スライス厚 $0.625 \mathrm{~mm}$, ビーム幅 $20 \mathrm{~mm}(0.625 \mathrm{~mm} \times 32)$ で, ヘリカルスキャンは

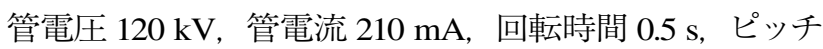
$0.531 ： 1$ ，スライス厚 $0.625 \mathrm{~mm}$ ，ビーム幅 $(0.625 \mathrm{~mm} \times 32)$ で Neuro3DFilter N1 を使用した。再構成関数は両者共 に Standard を使用し，どちらも撮影 FOVは $360 \mathrm{~mm}$, 再構成 FOVは $96 \mathrm{~mm}$ で行い, 画像処理ワークス テーション上で表示FOVを $40 \mathrm{~mm}$ に変更処理を 
行った。測定は 5 回行い,プロファイル作成時に平 均化した。

\section{1-3-2 Noise power spectrum (NPS) の比較}

ノンヘリカルスキャンとヘリカルスキャンから得ら れた MPRについて，ノイズの周波数成分に違いがあ るかを確認するために， $25 \mathrm{~cm} \phi$ 水ファントムを用い ノイズパワースペクトル測定を行った。スキャン条件． 再構成条件は，ノンヘリカルスキャンは管電圧 $120 \mathrm{kV}$, 管電流 $580 \mathrm{~mA}$, 回転時間 $1.0 \mathrm{~s}$, スライス厚 $5.0 \mathrm{~mm}$, ビーム幅 $20 \mathrm{~mm}(0.625 \mathrm{~mm} \times 32)$ ， ヘリカルスキャンは 管電圧 $120 \mathrm{kV}$ ，管電流 CT-AEC(NI: 6.5), 回転時間 $0.5 \mathrm{~s}$ ，ピッチ $0.531 ： 1$, スライス厚 $0.625 \mathrm{~mm}$ ，ビーム 幅 $(0.625 \mathrm{~mm} \times 32)$ で Neuro3DFilter N1 を使用し, 角 度構成を行わない元画像に平行なスライス厚 $8.0 \mathrm{~mm}$ のMPR を再構成した。ンヘリカルスキャン、ヘリ カルスキャンともに撮影 FOV $360 \mathrm{~mm}$, 再構成 FOV $250 \mathrm{~mm}$ とした.

\section{1-3-3 Contrast to noise ratio (CNR) の比較}

ノンヘリカルスキャンとヘリカルスキャン MPR の 低コントラスト分解能を比較するために，第二次勧告 に準拠した低コントラスト分解能評価用ファントム （以下，低コントラスト分解能ファントムとする)を用い, それぞれの画像における CNR の比較を行った，低コ ントラスト分解能ファントムには Fig. 1(a) に示すとお り CT 值の異なるさまざまな径のロッドが配置されて いる，ノンヘリカルスキャン，ヘリカルスキャンの撮 影，再構成条件は，1-3-2 と同様にした。

Fig. 1(b)に示したCT 值差 $5 \mathrm{HU}$ のセクションにお ける $20 \mathrm{~mm}$ 径のロッドについて, CNR を求めた5, 6).

Fig. 1(b)に示すとおり, 低コントラスト分解能ファン トム中に ROI を設定し，それぞれのロッドとバックグ ラウンドにおける CT 值とバックグラウンドの画像 SD を測定した。ロッド部分(信号部分)の CT 值を $\mathrm{HU}_{\mathrm{w}}$, ロッドのない部分(バックグラウンド部分)の CT 值を $\mathrm{HU}_{\mathrm{b}}$ ，画像 $\mathrm{SD}$ を $\mathrm{SD}_{\mathrm{b}}$ として以下に示す式よりそれぞ れのロッド径に打ける CNRを算出した。なお， SD 測定は 5 回のスキャンに扔ける測定值の平均とした.

$$
C N R=\frac{\left(H U_{w}-H U_{b}\right)}{S D_{b}}
$$

得られた各ロッド径の CNRについて，ノンヘリカ ルスキャンとへリカルスキャン MPR 間でそれぞれ paired t-test 検定を行った.

1-3-4 低コントラスト分解能ファントムの視覚評価

ノンヘリカルスキャンとヘリカルスキャン MPR の 低コントラスト分解能を比較するために，2-1-3 と同 一のファントムを用いて視覚評価を行った，撮影，再 構成条件は 2-1-2 と同様である. CT 值差が $5 \mathrm{HU}$ の
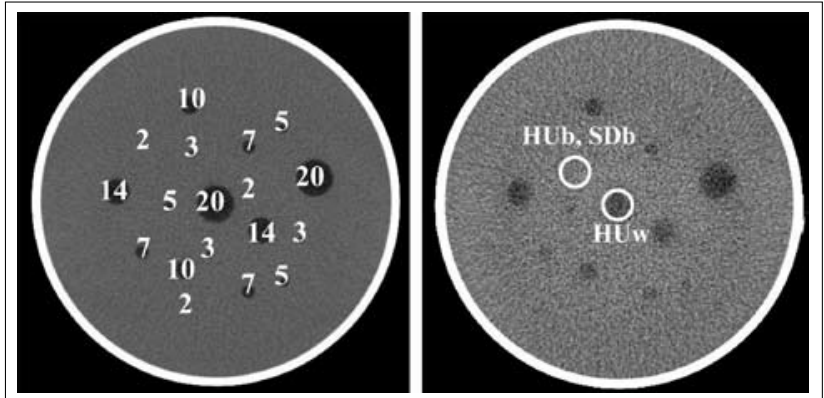

Fig. 1

(a) Low contrast resolution phantom and the diameters of objects. The unit of the diameter is " $\mathrm{mm}$ ".

(b) The CT value difference of this section is 5 $\mathrm{HU}$. ROI of SDb measures the SD at the part where an object is not included, and ROI of SDw measures the SD at the part where an object is included.

セクションのロッドにて評価を行ったが，急性期脳梗 塞はある程度広がりのある病変であることを考慮し，

今回は $20 \mathrm{~mm}, 14 \mathrm{~mm}, 10 \mathrm{~mm}$ 径のロッドについて それぞれ評価を行った。ノンヘリカスキャン，ヘリ カルスキャン MPR から得られたロッドが含まれる画 像(signal image) と含まれない画像(noise image)につ いて $(5 ：$ 明瞭に確認できる， 4 ：確認できる， $3 ：$ どち らともいえない，2：あまり確認できない，1：確認で きない)の 5 項目で評価を行った，評価はノンヘリカ ルスキャン, ヘリカルスキャン MPR それぞれ各ロッ ド径で行い, signal image 10 枚, noise image 10 枚を ランダムに配置しフィルム上で行った，表示条件はす ベて同一にし, window幅：80, windowレベル：35 に設定した。評価は経験 10 年以上の放射線技師 4 名 で行い, 各ロッド径の評価結果についてノンヘリカル スキャンとヘリカルスキャン MPR 間で Mann-Whitney's testにより検定を行った

\section{1-4 臨床評価}

\section{1-4-1 臨床例視覚評価}

MR 装置に扔ける拡散強調画像 (diffusion weighted image: DWI), MR angiography(MRA)により確定診 断された急性期脳梗塞臨床例 10 例について, ヘリカ ルスキャンで撮影を行った後 MPR を再構成し，その 早期虚血変化の検出能について検討を行った，へリ カルスキャンの撮影条件は 1-3-2 と同様であり, MPR は orbit metal $(\mathrm{OM})$ ラインに平行になるように作成した. 拡散強調画像はスピンエコー型 EPI，スキャン時間 1 分 12 秒, 繰り返し時間： $6000 \mathrm{~ms}$, エコー時間： $70.4 \mathrm{~ms}$, FOV： $230 \mathrm{~mm} ， 128 \times 128$ マトリクス, 励起回 数 : 3 , スライス厚 $: 5.0 \mathrm{~mm}$, スライスギャップ : $2.0 \mathrm{~mm}$, 受信バンド幅 $: \pm 250 \mathrm{kHz}, \mathrm{b}$ 值 $: 1000 \mathrm{~s} / \mathrm{mm}^{2}$, パラレ 


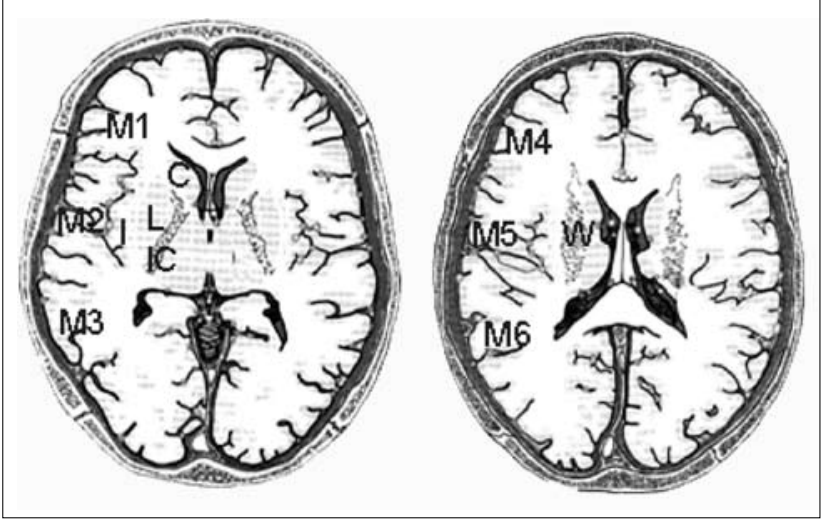

Fig. 2 Fill-in form of early ischemic change for visual evaluation in clinical cases.

ルイメージングを使用し, マルチコイルの感度補正を 行い撮像した. 対象は 63〜87 歳(平均 75.3 歳)の男性 6 名, 女性 4 名で, 片側頭蓋内内頸動脈閉塞 2 例, 片側中大脳動脈水平部閉塞 5 例, 片側中大脳動脈分 枝閉塞 3 例で, MRI 撮影開始より約 20 分後に CT 検 査を施行した. CT 画像の評価はフィルム上で行い, すべて同一の表示条件 window 幅：80, window レベル： 35 にて行った。評価は経験 10 年以上の放射線科医 1 名, 放射線技師 2 名で行い, 評価方法はAlberta stroke programme early CT score(ASPECTS)の評価法 を引用し ${ }^{1,7)}$, Fig. 2 に示す記入用紙に早期虚血変化 が認められる部位を記入した。

DWI については放射線科医 1 名が同様の評価を行 い,これをゴールドスタンダードとして DWI に対す る CT 画像の評価ポイント数の割合を求めた。なお, 本検討を行うにあたり, 当院倫理検討機関による承 認を受けた。

\section{1-4-2 被曝線量評価}

1-4-1 で撮影した臨床例 10 例における, 装置表示 の CTDIvol またDLPについて, 従来のノンヘリカル スキャンにおける頭部単純 CT の被曝と比較した.

\section{2. 結 果}

\section{2-1 ヘリカルスキャン撮影条件の設定}

ヘリカルスキャンにてスライス厚 $0.625 \mathrm{~mm}$, NI を 5.0〜10.5 まで変化させて撮影したデータから構築し た $5.0 \mathrm{~mm}$ 厚 MPR の画像 $\mathrm{SD}$ ，また管電流 $580 \mathrm{~mA}$, スライス厚 $5.0 \mathrm{~mm}$ のノンヘリカルスキャンの画像 SD を Fig. 3 に示す.

これよりへリカルスキャンにより得られた MPRに おいて, ノンヘリカルスキャンと同等の画像 SDを得 るためには, NI 5.0 で撮影する必要があることが示 唆された。

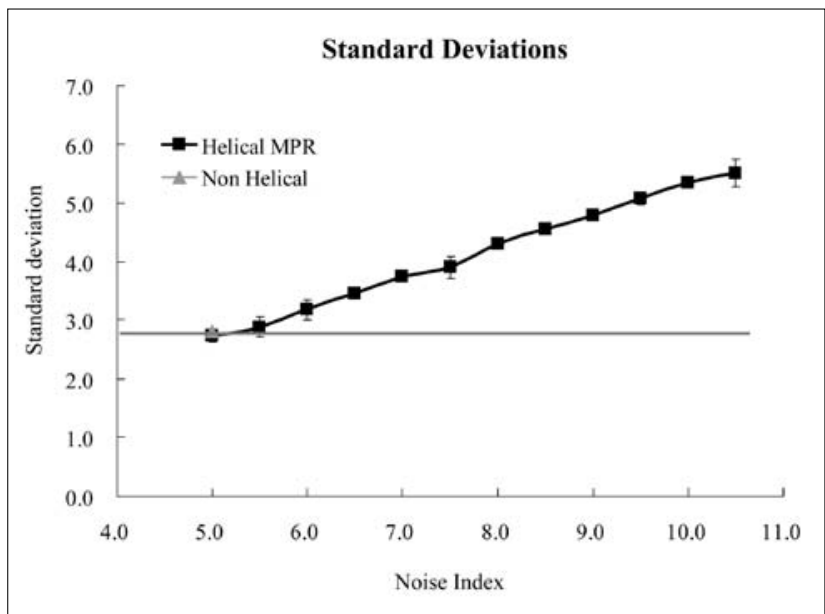

Fig. 3 Image SDs of MPR at NI 5.0 to 10.5 with helical technique and non-helical technique.

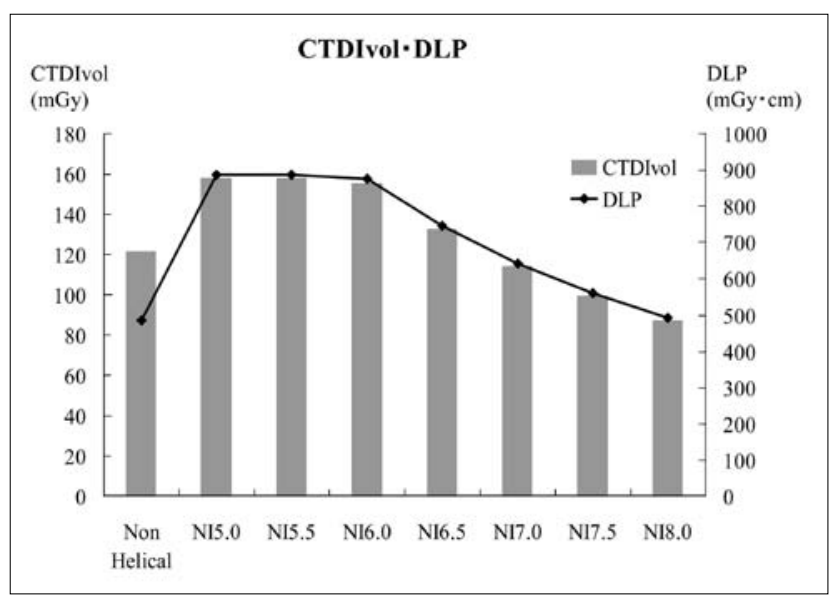

Fig. 4 CTDIvol and DLP of device display.

$25 \mathrm{~cm} \phi$ 水ファントムを用いて, 同一範囲 $(35 \mathrm{~mm})$ をノンヘリカルスキャンとヘリカルスキャンで撮影し たときの装置表示の CT dose index(CTDIvol)と dose length product(DLP)を Fig. 4 に示す.

Fig. 4 に示したとおり，ヘリカルスキャンにおいて ノンヘリカルスキャンと同等, もしくはそれ以下の CTDIvol, DLP とするためには，NI 7.0 以上に設定 する必要がある。しかし Fig. 3 の結果により同一の画 像 SD とするためには，NIの設定を 5.0 としなければ ならず, これでは大幅に被曝が増大してしまう.

MPR のスライス厚を 5〜10 mm に変化させたときの 画像 SD を Fig. 5 に示す.

Fig. 5 より, スライス厚 $5 \mathrm{~mm}$ のノンヘリカルスキャ ンと同等の画像 SDを得るためには, NI 6.5 ではスラ イス厚 $8 \mathrm{~mm}$, NI 7.0 ではスライス厚 $10 \mathrm{~mm}$ の MPR を構築する必要があることがわかった。再構成スライ ス厚が薄い方がパーシャルボリューム効果に対し有利 と判断し， ヘリカルスキャンのプロトコールは，管電圧 $120 \mathrm{kV}$, 管電流 CT-AEC: NI 6.5, 回転時間 $0.5 \mathrm{~s}$, スラ 


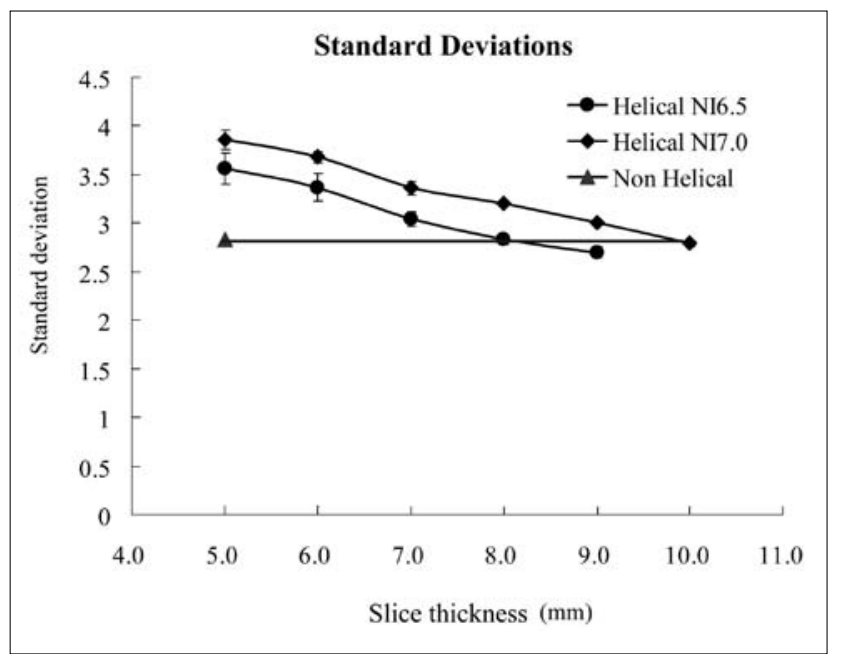

Fig. 5 Image SDs of MPR at slice thickness $5.0 \mathrm{~mm}$ to $10.0 \mathrm{~mm}$.

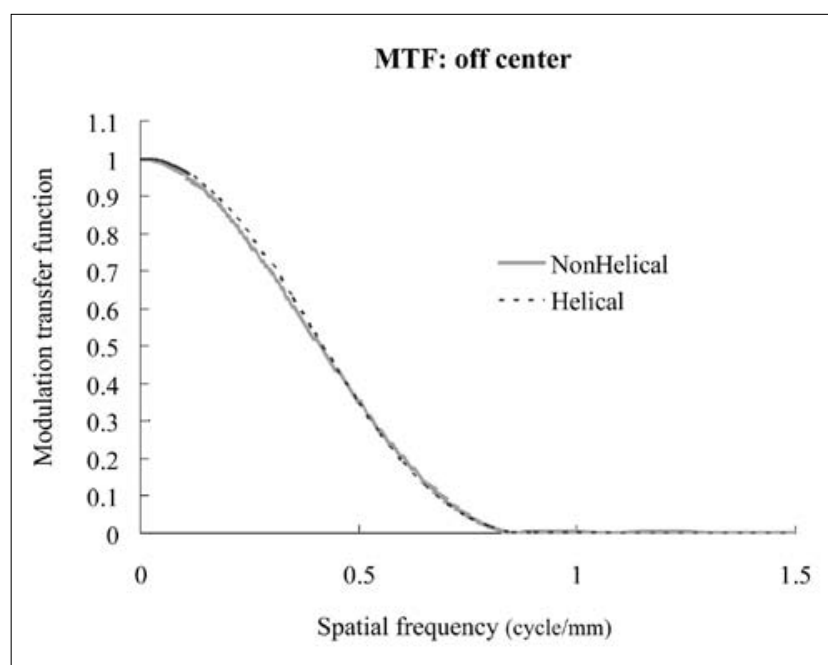

Fig. 7 MTF (in plane) of non-helical scanning and helical scanning. These are measured at the outside of 5 $\mathrm{cm}$ from center.

イス厚 $0.625 \mathrm{~mm}$, ビーム幅 $20 \mathrm{~mm}(0.625 \mathrm{~mm} \times 32)$, ピッチ 0.531 : 1, 再構成関数 Standard, Neuro3DFilter を使用して撮影を行い, 8.0 mm MPR を再構成す ることとし，今回の検討においてはこの撮影条件にて 検討を行った.

\section{2-2 物理特性評価}

\section{2-2-1 スライス面内 MTF の比較}

ノンヘリカルスキャンとヘリカルスキャンの FOV 中心部でのスライス面内 MTFを Fig. 6 に, FOV 中 心より $5 \mathrm{~cm}$ 外側の MTF を Fig. 7 に示す.

FOV 中心部および FOVより $5 \mathrm{~cm}$ 外側ともに両者 の $10 \% \mathrm{MTF} に$ に相違は認められなかった。

\section{2-2-2 NPS の比較}

ノンヘリカルスキャンとヘリカルスキャン MPRの

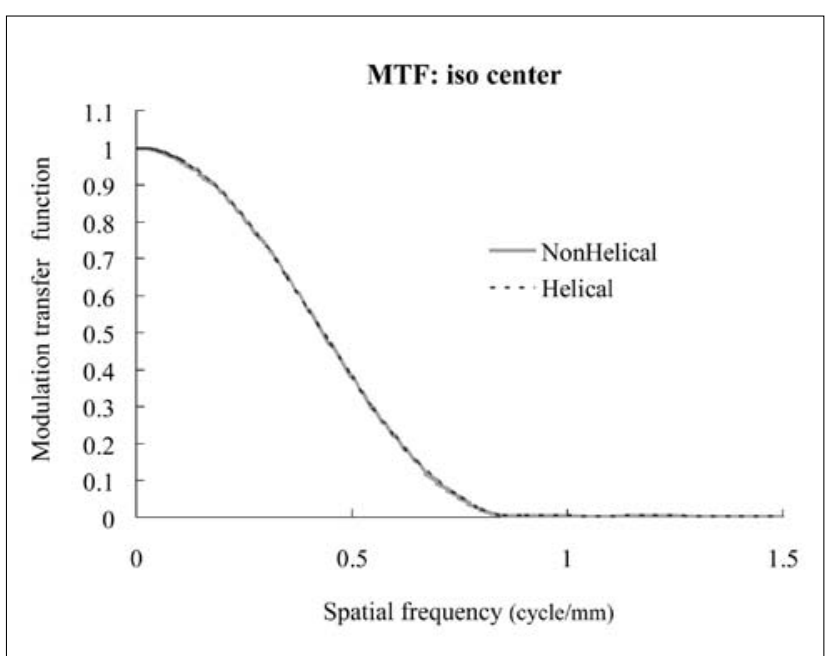

Fig. 6 MTF (in plane) of non-helical scanning and helical scanning. These are measured on center.

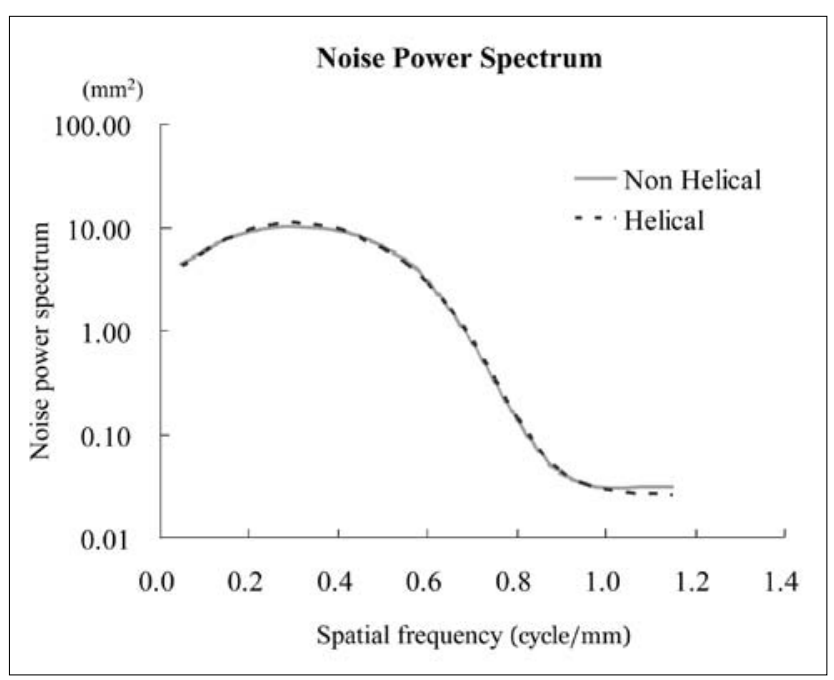

Fig. 8 NPS of non-helical scanning and MPR by helical scanning.

ノイズパワースペクトルを Fig. 8 に示す.

すべての周波数帯域において，ノイズレベルに差 を認めなかった。

\section{2-2-3 CNR の比較}

$20 \mathrm{~mm}$ 径のロッドにおけるノンヘリカルスキャンと

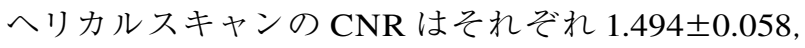
$1.348 \pm 0.037$ となり, ノンヘリカルスキャンとへリカル スキャンの CNR に有意差を認めなかった。

2-2-4 低コントラスト分解能ファントムの視覚評価 評価に使用した低コントラスト分解能の画像を Fig. 9 に $20 \mathrm{~mm}, 14 \mathrm{~mm}, 10 \mathrm{~mm}$ 径におけるノンヘリカル スキャンとへリカルスキャン MPR の視覚評価結果を Table 1 に示す.

両者の感度，特異度に有意差を認めなかった. 


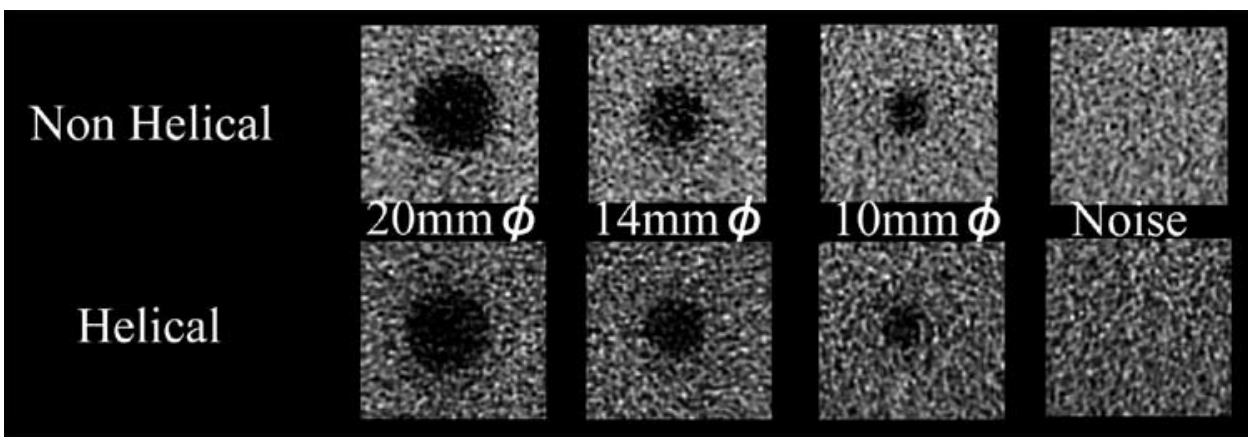

Fig. 9 Images of the low contrast resolution phantom for visual evaluation.

Table 1 The visual evaluation of low contrast resolution phantom, sensitivities and specificities of objects of $20 \mathrm{~mm}, 14 \mathrm{~mm}$, and $10 \mathrm{~mm}$ in section of $5 \mathrm{HU}$

\begin{tabular}{lcccccccc}
\hline \hline & \multicolumn{3}{c}{ Sensitivity (\%) } & & \multicolumn{3}{c}{ Specificity (\%) } \\
\cline { 2 - 4 } \cline { 7 - 8 } Diameter of rod & $20 \mathrm{~mm}$ & $14 \mathrm{~mm}$ & $10 \mathrm{~mm}$ & & $20 \mathrm{~mm}$ & $14 \mathrm{~mm}$ & $10 \mathrm{~mm}$ \\
\hline Non helical & 100 & 100 & 95 & & 100 & 100 & 100 \\
Helical & 100 & 100 & 100 & & 100 & 100 & 100 \\
\hline
\end{tabular}
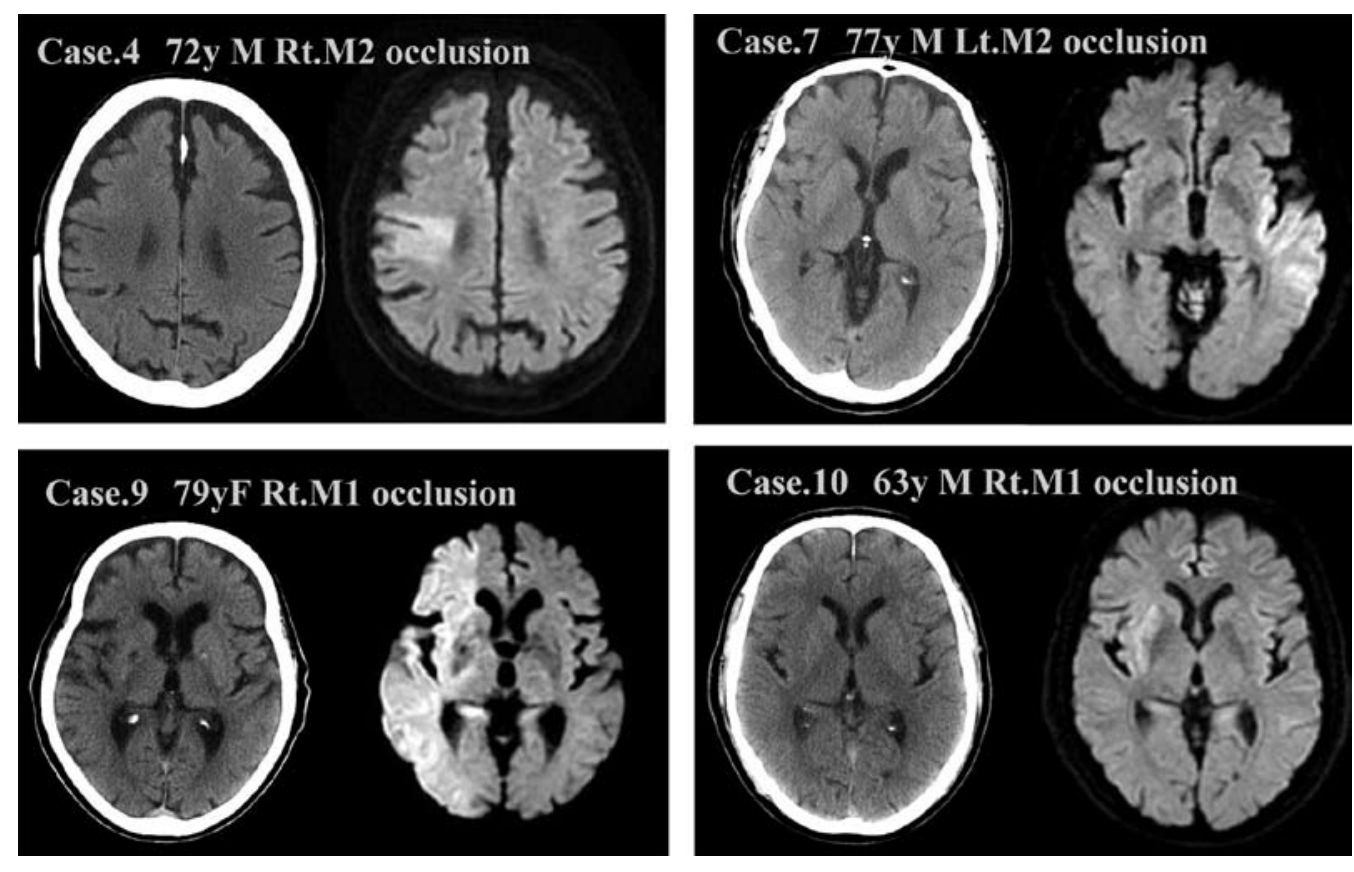

Fig. 10 Clinical cases

Left: MPR by helical scanning. Right: DWI.

\section{2-3 臨床評価}

\section{2-3-1 臨床例視覚評価}

Fig. 10 に今回評価を行った臨床例 4 例を示す.

また，各評価者の視覚評価結果を Table 2 に，視 覚評価により求められたへリカルスキャン MPR 臨床 画像の感度, 特異度, 陽性予測值, 陰性予測值を Table 3 に示す.

評価者間での感度・陽性予測值の標準偏差が特異 度・陰性予測值に比べやや高い傾向になった．総じて
感度に比べ特異度が高い傾向であった。

\section{2-3-2 被曝線量評価}

ヘリカルスキャンを行った臨床例 10 症例における 装置表示の CTDIvol と DLP, また通常臨床で用いて いるノンヘリカルスキャン頭部単純 CT における DLP を Fig. 11 に示す.

9 症例において, ヘリカルスキャンのDLPが高い 值を示した。 
Table 2 The result of the visual evaluation in clinical cases

\begin{tabular}{ccccc}
\hline \hline Case & Observer 1 & Observer 2 & Observer 3 & DWI \\
\hline 1 & 4 & 3 & 4 & 8 \\
2 & 0 & 0 & 0 & 4 \\
3 & 10 & 3 & 9 & 10 \\
4 & 1 & 2 & 0 & 7 \\
5 & 0 & 1 & 0 & 3 \\
6 & 1 & 1 & 1 & 1 \\
7 & 0 & 0 & 0 & 5 \\
8 & 2 & 2 & 2 & 2 \\
9 & 10 & 10 & 3 & 10 \\
10 & 2 & 2 & 2 & 2 \\
\hline
\end{tabular}

Table 3 Sensitivities, specificities, positive predictive values, and negative predictive values of the visual evaluation in clinical cases

\begin{tabular}{lcccc}
\hline \hline & Sensitivity (\%) & Specificity (\%) & $\begin{array}{c}\text { Positive } \\
\text { predictive } \\
\text { value (\%) }\end{array}$ & $\begin{array}{c}\text { Negative } \\
\text { predictive } \\
\text { value(\%) }\end{array}$ \\
\hline Observer 1 & 52.6 & 96.3 & 83.3 & 85.3 \\
Observer 2 & 61.4 & 90.8 & 70.0 & 87.1 \\
Observer 3 & 42.1 & 100 & 100 & 83.2 \\
Average & 52.0 & 95.7 & 84.4 & 85.2 \\
SD & 9.7 & 4.6 & 15.0 & 2.0 \\
\hline
\end{tabular}

\section{3. 考 察}

従来から頭部単純 CT は,ノンヘリカルスキャンで 行うことが通例である。特に急性期脳梗塞の診断は 画質の低下が予測されるため，ヘリカルスキャンの使 用が避けられてきた1)。しかし X 線管球や検出器の 性能向上など，近年装置の進歩により頭部単純 CT の撮影法においてもへリカルスキャンの利点を生かせ るのではないかと考える。

物理特性評価においてノンヘリカルスキャンとへリ カルスキャンの $10 \%$ MTF に相違は認められなかった.

これは本装置では回転速度に関わらずview 数が変わ らないことが起因していると思われる。この MTFの 結果により両者のスライス面内空間分解能は同等で あることが示唆された。 また同一画像 SDのノンへリ カルスキャンとヘリカルスキャン MPR では, ノイズ の周波数分布はほほ同等であり，低コントラスト分解 能ファントムにおける視覚評価においても有意差を認 めなかった。また CNRの測定結果においても両者に 有意差を認めず，ノンヘリカルスキャンとヘリカルス キャン MPR は物理評価上同等の画質であると考えら れた。しかし，今回設定した撮影条件においては，ノ ンヘリカルスキャンの設定スライス厚 $5 \mathrm{~mm}$ とへリカ ルスキャン MPR のスライス厚 $8 \mathrm{~mm}$ に $3 \mathrm{~mm}$ の違いが ある.今回の検討項目には含めていないが, このスラ

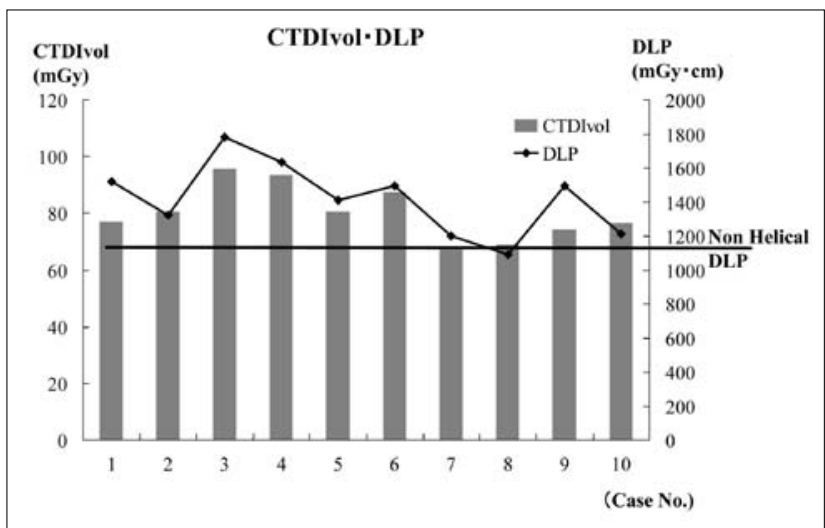

Fig. 11 CTDIvol and DLP of device display in 10 clinical cases.

イス厚の違いはパーシャルボリュームに影響を与える ものと予測される.

発症 6 時間以内の急性期脳梗塞において, DWI は 感度 91〜 100\%, 特異度は 95〜100\%であるのに対し, ノンヘリカルスキャンの頭部単純 CT では感度 46〜 55\%，特異度は 56〜100\%との報告がある ${ }^{8 \sim 11)}$.

今回設定したへリカルスキャン MPR による頭部単 純 CT の評価結果は，過去に報告されていたノンへリ カルスキャンによる急性期脳梗塞 CT の評価結果 ${ }^{8 \sim 10}$ と矛盾しない結果であった。これより，今回設定した 撮影条件は妥当であり，また今回評価した症例に関 
しては，設定スライス厚の違いによる影響はなかった ものと考えられ, ヘリカルスキャンによる MPR 画像 は急性期脳梗塞における早期虚血変化の検出が可能 であると示唆された

通常のノンヘリカルスキャンではほぼすべての症例 に対し同一の撮影条件を設定しているが, ファントム 実験により得られた最適画像 SD 2３になるような 撮影条件でも，体型や年齢による違いにより最適画 像 SD の範囲外になり得る。しかし, 今回は CT-AEC を使用することにより画像 SD を最適化することが可 能となり，これもへリカルスキャンを臨床に用いる大 きな利点であると考える。しかし実際の頭部単純 CT では，複雑な骨構造によるアーチファクトなどによ り，予測不能な画質劣化があることも考えられる。今 回は基底核レベルにおける急性期脳梗塞の判定目的 に撮影条件を考えたが，臨床において全脳をカバー する範囲の撮影を考慮すると, 特に後頭蓋窩レベル はビームハードニングや非線形パーシャルボリューム アーチファクト対策が必要であり, ヘリカルスキャン に起因するアーチファクトによる画質劣化も考慮しな ければならない12)。さらに，へリカルスキャンではス
キャンの開始・終了の画像に寄与しない被曝の増加は 避けられず，従来のノンヘリカルスキャンと同等の画 質，つまり急性期脳梗塞の早期虚血病変を検出する ためには，被曝線量の増加は避けられないことも確 認できた。 しかし, 臨床例の中には従来のノンヘリカ ルスキャンよりもDLPが低い症例も認められた。こ のような症例に対しては, CT-AECを使用したへリカ ルスキャンにおいて，適正な線量で最適な画質を得 ることができたと考えられる。

\section{4. 結 語}

今回の検討では大脳基底核レベルに対して，へリ カルスキャンを臨床に用いても診断には影響がない 可能性が示唆された。しかし，CTにおける早期虚血 変化は非常に軽微な変化であり，また物理特性の異 なった装置では必ずしも同様の結果となるとは限ら ず，ヘリカルスキャンの適用や撮影条件の設定は, 被曝線量を考慮しつつ慎重に行う必要がある。

本論文の要旨は，日本放射線技術学会第 65 回総 会学術大会 (2009 年，横浜)にて発表した。

\section{参考文献}

1）興梠征典, 渡邊嘉之, 佐々木真理 編集. ASIST-Japan 実践 ガイドライン策定委員会, 急性期脳梗塞画像診断実践ガイ ドライン 2007. 東京：南江堂, 2007.

2) 宝金清博 編著. 脳血行再建の理論と実際. 東京 : 中外医 学社, 2006 .

3) 岩井喜典 編著. 電子工学進歩シリーズ(9) X 線コンピュータ 断層装置. 東京 : コロナ社, 1973.

4) 松原 望, 縄田和満, 中井検裕. 統計学入門 東京大学 教養学部統計学教室編. 東京: 東京大学出版会, 1994.

5）市川勝弘，村松禎久 編著。標準 X 線 CT 画像計測。東京： オーム社, 2009.

6）片倉俊彦, 森一生, 辻岡勝美, 他. MDCT 装置の性能 評価に関する基準案の提案班報告. 日放技学誌 2009; 65(4): 491-502.

7) Mak HKF, Yau KKW, Khuong PL, et al. Hypodensity of $>1 / 3$ middle cerebral artery territory versus Alberta stroke programme early CT score (ASPECTS): Comparison of two methods of quantitative evaluation of early CT change in hyperacute ischemic stroke in the community setting. Stroke 2003; 34(5): 1194-1196.
8) Fiebach JB, Schellinger PD, Jansen O, et al. CT and diffusionweighted MR imaging in randomized order: Diffusionweighted imaging results in higher accuracy and lower interrater variability in the diagonosis of hyperacute ischemic stroke. Stroke 2002; 33(9): 2206-2210.

9) Mullins ME, Schaefer PW, Sorensen AG, et al. CT and conventional and diffusion-weighted MR imaging in acute stroke: study in 691 patient at presentation to the emergency department. Radiology 2002; 224(2): 353-360.

10) Hill MD, Rowley HA, Adler F, et al. Selection of acute ischemic stroke patients for intra-arterial thrombolysis with pro-urokinase by using ASPECTS. Stroke 2003; 34(8): 1925-1931.

11) Urbach H, Flacke S, Keller E, et al. Detectability and detection rate of acute cerebral hemisphere infarcts on CT and diffusion-weighted MRI. Neuroradiology 2000; 42(10): 722-727.

12) Jones TR, Kaplan RT, Barton Lane, et al. Single-versus multi-detector row $\mathrm{CT}$ of the Brain: Quality assessment. Radiology 2001; 219(3): 750-755. 


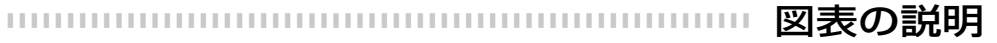

Fig. 1 (a) 低コントラスト分解能ファントム画像とそのロッド径

(b) 低コントラスト分解能ファントム CT 值 5 HU セクションにおける ROI 設定

Fig. 2 臨床例視覚評価記入用紙

Fig. 3 Noise index を5.0〜 10.5 まで変化させて撮影したデータから構築した $5.0 \mathrm{~mm}$ 厚 MPR の画像 SD, また管電流 $580 \mathrm{~mA}$, スライス厚 $5.0 \mathrm{~mm}$ のノンヘリカルスキャンの画像 $\mathrm{SD}$

Fig. $425 \mathrm{~cm} \phi$ 水ファントムを用いて, 同一範囲 $(35 \mathrm{~mm})$ をノンヘリカルスキャンとヘリカルスキャンで撮影したときの装置表示の CTDIvol と dose length product(DLP)

Fig. 5 25cm申 水ファントムを用いてスキャンを行い，MPR のスライス厚を 5 10 mm に変化させたときの画像 SD

Fig. 6 ノンヘリカルスキャンとヘリカルスキャンの撮影 FOV 中心部におけるスライス面内 MTF

Fig. 7 ノンヘリカルスキャンとヘリカルスキャンの撮影 FOV 中心部より $5 \mathrm{~cm}$ 外側に扔けるスライス面内 MTF

Fig. 8 ノンヘリカルスキャンとヘリカルスキャン MPR のノイズパワースペクトル

Fig. 9 評価に使用した低コントラスト分解能ファントムの画像

Fig. 10 ヘリカルスキャン MPR と同一症例における拡散強調画像の臨床例

Fig. 11 ヘリカルスキャンを行った臨床例 10 症例に扔ける装置表示の CTDIvol とDLP, また通常臨床で用いているノンへリカル スキャン頭部単純 CT に扔ける DLP

Table 1 低コントラスト分解能評価用ファントム, $5 \mathrm{HU}$ のセクションにおける $20 \mathrm{~mm}, 14 \mathrm{~mm}, 10 \mathrm{~mm}$ のロッドの感度, 特異度 Table 2 臨床例視覚評価結果

Table 3 臨床例視覚評価の感度, 特異度, 陽性的中率, 陰性的中率 